\title{
AS DIVERGÊNCIAS IDEOLÓGICAS DAS ESCOLAS DE SAMBA DO RIO DE JANEIRO NO PERÍODO MILITAR: DIFERENÇAS E APROXIMAÇÕES
}

\author{
Edson Bellucci ${ }^{1}$ \\ Maria Angélica Perez Bellucci ${ }^{2}$ \\ Valéria Regina Zanetti ${ }^{3}$
}

Resumo: O presente trabalho consiste em mostrar as escolas de samba como forma de expressão popular, suas divergências ideológicas durante a ditadura militar (1964 - 1968), e como algumas destas agremiações através de seus enredos criticavam o regime e outras se aproximaram dele. Neste período as escolas de samba do Rio de Janeiro enfrentaram diversos desafios para a composição de seus enredos, uma vez que o sistema político organizado controlava toda e qualquer manifestação cultural no Brasil, através de seus órgãos de repressão, as inquietações e diferenças foram evidenciadas através dos sambas de enredo, onde algumas agremiações criticaram o regime e outras se aproximaram dele.

Palavras-chave: Samba Enredo; Ditadura Militar; Divergências.

\footnotetext{
1 Universidade do Vale do Paraíba, Brasil. E-mail: edsbell@yahoo.com.br.

2 Universidade do Vale do Paraíba, Brasil. E-mail: mapbellucci@yahoo.com.br.

3 Universidade do Vale do Paraíba, Brasil. E-mail: vzanetti@univap.br.
} 